\title{
Women, violent crime and criminal justice in Georgian Wales
}

\author{
KATHERINE D. WATSON*
}

ABSTRACT. This article examines encounters of women with the criminal justice system in Wales during the century before the Courts of Great Sessions were abolished in 1830. Drawing on evidence from cases of sexual assault and homicide, it argues that women who killed were rarely convicted or punished harshly. A gendered discretion of sorts also acted against rape victims, as trials never resulted in conviction. Using violence as a lens, the paper reveals a distinctively Welsh approach to criminal justice, and offers quantitative evidence on which further comparative studies of the history of law and crime in England and Wales may be based.

\section{INTRODUCTION}

The procedures through which the criminal law was enforced cannot be separated from the social, cultural and economic settings in which the law functioned. ${ }^{1}$ Connections of this sort are nowhere more evident than in relation to violence, which historians have identified as a major indicator of changing values and attitudes on the part of the state, concerning the use of physical punishments, ${ }^{2}$ and on that of the general population, regarding the propensity to commit or prosecute acts of interpersonal violence. ${ }^{3}$ Since women have been both under-represented in historical encounters with the criminal justice system and subject to gendered expectations of behaviour, their experiences as both the victims and perpetrators of violence provide an important means of assessing the impact of socio-cultural contexts and circumstances on the boundaries of acceptable conduct. ${ }^{4}$

This article uses quantitative and qualitative data from Georgian Wales to investigate the experience of women of two significant forms of

\footnotetext{
* Department of History, Philosophy and Religion, Oxford Brookes University.
} 
interpersonal violence: as victims of sexual assault and perpetrators of homicide. It thus adopts a holistic perspective absent from most historical studies of gender and crime in Britain, which consider women as either victims or perpetrators. ${ }^{5}$ Moreover, comparisons with English findings in the same period test the degree to which the Welsh differed in their use and experience of the criminal law. Such a methodology permits novel insights into the gendered nature of criminal justice from two different female perspectives, while the focus on Welsh women, whose history has only recently begun to be explored, ${ }^{6}$ contributes to our understanding of gender distinctions in one of the most under-researched constituent nations of the United Kingdom. Indeed, in comparison with the extensive historiography of violence and criminal justice in England, ${ }^{7}$ there has been little research on the relationship of the Welsh people to the criminal justice system and less still examining gender, crime and violence in the Principality. ${ }^{8}$ Given that England and Wales were united both legally and administratively in the mid-sixteenth century yet possessed very different cultural identities and, until 1830, separate court systems, a study of Welsh women's experience of violence is imperative in facilitating comparative studies of crime and the gendered functioning of the criminal justice system in the British Isles. ${ }^{9}$

The Tudor state imposed its own retributive form of justice on Wales, but the Welsh had a long tradition of compensation and arbitration. ${ }^{10}$ Given variations in legal practice as a further complicating factor, we should not assume that the criminal law, which was nominally the same in both countries, was actually applied in the same way when the courts were confronted by female victims and defendants. Nonetheless, John Minkes has tentatively suggested that, despite language barriers, the criminal courts in Wales 'differed from their English counterparts only in name'. ${ }^{11}$ As in England, the Welsh legal system operated in a largely discretionary fashion which might have tended to benefit women. ${ }^{12}$ How did this discretion work in practice? How and why did Welsh women come to be the victims or perpetrators of violence, how did they come to the attention of the higher courts and, once there, what was their fate? Did the criminal justice system react differently to female offenders than it did to male offenders, or privilege certain victims over others? The English historiography makes much of the pardoning process, ${ }^{13}$ but this article will show that the Welsh experience was exceptional in that so few violent female offenders had need of pardon: Welsh juries pre-empted the power of the state by wielding their verdict for the defendant, ensuring that she got off lightly. Similarly, the Welsh were markedly reluctant to invoke capital punishment for crimes of violence against women unless there was both strong evidence and an assumption that the seriousness of the crime 
merited execution, ${ }^{14}$ providing a powerful impediment to the conviction of accused rapists. Using violence as a lens, this paper reveals a distinctively Welsh approach to criminal justice.

\section{THE WELSH COURTS OF GREAT SESSIONS}

The Welsh Courts of Great Sessions were created as part of the Tudor process of annexation aimed at creating a national sovereign state. The Act of Union of 1536 brought Wales into the same administrative system as England under one uniform law. One of its key clauses stated that no Welsh speaker could hold public office unless he was fluent in English. The second Act of Union of 1543 established the Courts of Great Sessions, which convened twice a year in 12 Welsh counties, had complete jurisdiction over capital offences such as robbery, rape and homicide, and could try indictable misdemeanours such as assault and buying stolen goods. Eight judges, who were wholly independent of the English courts and eventually gained a reputation as inferior in legal capabilities because they were appointed by the Treasury rather than the Lord Chancellor, travelled four circuits: North Wales (covering the counties of Anglesey, Caernarfon and Merioneth); Chester (Flint, Denbigh, Montgomery); Carmarthen (Carmarthen, Cardigan, Pembroke); and Brecon (Brecon, Glamorgan, Radnor). ${ }^{15}$ The official language of the courts' records was Latin until 1733, and thereafter English, but 'the administration of the law in Wales could never have operated effectively without the informal and frequent use of the Welsh language in the courts' ${ }^{16}$ Although early modern jurors were not necessarily bilingual, grand jurors and jury foremen probably were. The judges, on the other hand, were almost without exception solely English-speaking, while witnesses and defendants were almost entirely Welsh speaking. ${ }^{17}$ The use of interpreters was common in court, however, and by the early eighteenth century the work seems to have been done by professionals for a fee of 2 shillings (2s.) per trial. A similar system of court translators was used in Ireland until the mid-nineteenth century, but there the work was done by salaried appointees: in the 1760s the translator for the County Donegal assizes was paid $£ 2$ per year for what was probably a part-time position. ${ }^{18}$ In Wales, financial records show that court interpreters were always paid a trial fee, not a salary, which rose rapidly around the 1750 s, reached a national standard of 10 shillings and 6 pence (10s. 6d.) by the 1790s and remained at that level until $1830 .{ }^{19}$ Double fees were sometimes allowed for lengthy trials involving 10 or more witnesses. ${ }^{20}$ Interpreters were not named in the bills arising from criminal cases, but occasionally appear in the costs of civil actions. ${ }^{21}$ 
Although there is little sign of this language barrier in the written evidence submitted to the court, witness statements were created by a process of translation: deponents gave sworn testimony to a magistrate (also known as a justice of the peace or JP) or coroner in Welsh, and the official, or his clerk, wrote it down in English. Welsh words were preserved only where the exact meaning was of particular importance or interest, ${ }^{22}$ mirroring the procedures that had been followed in the medieval and Tudor church courts, when deponents had testified in English but clerks recorded their words in Latin. ${ }^{23}$ It is impossible to know how accurately the surviving depositions reflect what was actually reported by victims and witnesses, many of whom were illiterate and could not read the declarations that they put their mark to, but this intermediate step gives an added nuance to the important role played by local officials in the criminal justice system. Welsh and English magistrates screened the cases sent for trial at Great Sessions and the assizes. They could use a range of informal sanctions such as undervaluing stolen goods, issuing sureties for good behaviour or arbitration to keep cases out of court altogether or ensure that they were heard at quarter sessions, which were county courts that dealt with non-capital offences such as common assault, petty larceny, fraud and assorted conduct-related misdemeanours. ${ }^{24}$

Cases prosecuted at Great Sessions relied on a county-wide network of justices who were responsible for investigating allegations, taking depositions and submitting them to the court, and for binding prosecutors and witnesses to appear. Coroners (two per county plus a small number of franchise coroners) had an identical role in homicide cases, but could not act until they had received information from the public. Local constables executed arrest warrants. The number of justices increased during the eighteenth century as a wider cross-section of society - including lesser squires, clerics, doctors, merchants and lawyers - met the property qualification of $£ 100$ and sought the status that membership of the Commission of the Peace bestowed. However, the majority were non-resident in the county or inactive. ${ }^{25}$ The potential for delays in proceedings was compounded by the inability of the Courts of Great Sessions to summon anyone resident outside the county jurisdiction, a problem that grew with the increasing mobility of the population. ${ }^{26}$

As the avowed reason for the creation of the Courts of Great Sessions was to assimilate the supposedly lawless Welsh to English law and habits, the late Georgian period was a turning point because it was towards the end of the eighteenth century that parliamentary agitation for their abolition began. Not only did the salaries of the judges seem excessive in relation to their markedly small workload, but also arguments against the continued existence of Great Sessions noted that centuries of change had 
removed most of the reasons for resorting to local jurisdiction. Eventually, against the wishes of the Welsh people and Welsh Members of Parliament, a lack-lustre minority who were easily out-voted, the Courts of Great Sessions were abolished by an Act of Parliament; 1 William IV, c.70, in $1830 .^{27}$ Thereafter, the English assize system was expanded to incorporate three more judges and two new circuits: North and South Wales.

One of the most noteworthy features of the documentary evidence compiled by Great Sessions is its comprehensiveness: the criminal records are more complete than their English assize counterparts. For the Chester circuit 99.7 per cent of the records from the final century of the existence of the Courts survive. For North Wales, Brecon and Carmarthen the survival rates were 100 per cent, 97.5 per cent and 85.9 per cent, respectively. ${ }^{28}$ This voluminous archive, housed at the National Library of Wales, includes indictments, depositions, minute books, writs, affidavits, recognisances, inquisitions, calendars, jury lists, bills, pardons and even the occasional confession. Information collated from all these sources has been entered into an online searchable database that holds details of every individual, including persons unknown, recorded in records surviving from between 1730 and 1830 . Offences have been categorised by type; annotations provide further particulars where these exist, and information in Welsh and Latin has been translated. ${ }^{29}$ The resulting resource allows a degree of comparative quantification that was previously difficult to achieve, and thus forms the foundation of the present study, part of a larger project on violent crime. It is the female violent offenders in the database who form the focus of this article.

Table 1 indicates the crimes tried at Great Sessions that have been selected for examination. Sexual assaults, homicides and serious injuries represent the extreme end of a spectrum of violence, ${ }^{30}$ forming perhaps just a fifth of all offences against the person, but this is offset by the fact that the files documenting these cases include a higher proportion of depositions and trial outcomes than those referring to the much more numerous minor assaults. The dataset does not provide a record of absolute levels of violence, however, documenting only those offences brought to the attention of the authorities; it is thus subject to the usual provisos about the so-called 'dark figure' of unknown or unreported crime. ${ }^{31}$ Offences have been categorised by staff at the National Library of Wales and so to some extent represent post hoc definitions. This is why the broader category of 'domestic violence' cannot be approached directly. Moreover, errors and omissions can be identified, but these are few, and the evident consistency with which key terms and phrases have been used 
T ABLE 1

Number of accusations of violent offences before the Court of Great Sessions, Wales, 1730-1830

\begin{tabular}{lccccc}
\hline \hline & $\begin{array}{c}\text { No. of } \\
\text { Offence }\end{array}$ & $\begin{array}{c}\text { No. of } \\
\text { females } \\
\text { accused }\end{array}$ & $\begin{array}{c}\text { Noparate } \\
\text { sepases } \\
\text { cases }\end{array}$ & $\begin{array}{c}\text { No. of cases } \\
\text { involving } \\
\text { defendant }\end{array}$ & $\begin{array}{c}\text { with sole female } \\
\text { defendant }\end{array}$ \\
\hline Rape & 58 & $4^{a}$ & 49 & 1 & 0 \\
Attempted rape & 111 & 2 & 89 & 2 & 0 \\
Infanticide & $197^{b}$ & 186 & 178 & $16^{c}$ & 161 \\
Murder & $686^{d}$ & 64 & 446 & 98 & 31 \\
Attempted murder & 374 & 77 & 144 & 38 & 2 \\
Manslaughter & 143 & $5^{e}$ & 124 & 5 & 5 \\
Malicious shooting & 57 & $5^{f}$ & 35 & 3 & 0 \\
Malicious wounding & 26 & 0 & 20 & 0 & 0 \\
Total & 1652 & 343 & 1090 & 163 & 197 \\
\hline \hline
\end{tabular}

a All members of the same Gypsy family, indicted for aiding and abetting a rape.

${ }^{b}$ Includes three cases against person(s) unknown in which no indictment was laid, one woman indicted twice, and one woman not included in the online database.

${ }^{c}$ Includes eight indictments against men (all charged with a woman), seven indictments against two women, and one indictment against three women.

${ }^{d}$ Includes 21 murders by person(s) unknown (18 separate cases), 1 woman and 6 men indicted twice for the same offence, and 5 men indicted for multiple murder.

$e$ Of whom three were, technically, accused of infanticide.

${ }^{f}$ Four women of whom one was indicted for two separate but related offences.

Source: National Library of Wales, Crime and Punishment database. 'Accusations' includes all allegations recorded by the court, whether or not a prosecution ensued.

to define offences suggests that the database may be confidently used as a means of gauging proportional amounts of reported crime. Finally, it should be noted that the sources were assembled on behalf of the victim by legal officers who were required to record only what would prove the felony, and so provide more insights into their attitudes than into those of the accused or the jurors who sat in judgement upon them. Nonetheless, the depositions offer a unique window into community opinion and morality, and thus illuminate contemporary ideas about gender and violence in Wales.

\section{RAPEAND SEXUAL ASSAULT}

The historiography of rape in early modern England has identified the most distinctive features of the crime: it was infrequently prosecuted, a high proportion of the victims were children, medical evidence was fairly common, and conviction rates were much lower than for most other 
felonies. These characteristics were a direct consequence of the law, which defined rape as "carnal knowledge of a woman forcibly and against her will' or as sex with a girl under the age of 10 years, with or without consent; boys under the age of 14 years could not be guilty of it. Women were expected to show clear evidence that they had resisted, children had to provide supporting testimony, penetration and ejaculation were normally required proof, the narrative had to be told in such a way as to preserve the modesty of the victim, and the oft-quoted maxim of Lord Hale favoured men: "it is an accusation easy to be made, hard to be proved, but harder to be defended by the party accused, though innocent ${ }^{32}$ Acquittal on a rape charge did not preclude subsequent prosecution for the attempt to rape, an indictable misdemeanour which did not require evidence of penetration and for which it was quite legal to reach an out-of-court financial settlement. It is therefore possible that in many cases indicted as attempts, the sexual act had, in fact, been completed. ${ }^{33}$

The records of the Courts of Great Sessions over the study period reveal 58 allegations of rape and 111 of attempted rape against named individuals, six of whom were women charged with aiding and abetting. Twelve men were indicted for both offences and seven of them were convicted of the lesser charge. Some cases involved multiple attackers, usually two but sometimes more. Half the victims were children or unmarried and thus in positions of weakness relative to adult males, but a significant number of married women brought their cases to court (Table 2). The outcomes for women who took the time, expense and emotional effort to prosecute their attackers were disappointing given that over half of those charged with rape were not tried at Great Sessions, and of the cases that reached a jury and for which an outcome is known, none resulted in conviction (Table 3). This is a lamentable statistic even in comparison with the low figures of conviction for rape found in London (where only 17 per cent of rape cases brought to trial between 1730 and 1830 resulted in a conviction) ${ }^{34}$ Surrey (14.7 per cent, $\left.1660-1800\right),{ }^{35}$ and north-east England ( 2 convictions from 15 prosecutions for the rape of adults, 1770-1800). ${ }^{36}$ Two factors help to explain the very low conviction rate in Wales.

Some Welsh plaintiffs accepted payment to drop a prosecution, as happened in 1763 when diarist William Thomas noted: 'About this 14 days past Mallet the Supervisor, who lives at Burthin [near Cowbridge], ravished his servant maid, about 18 years of age. She served him with a warrant, he feared to be punished, determined the matter and paid her $£ 10$ for abuseing her ${ }^{37}$ It is unlikely that such a large sum could have been obtained from the average defendant and the suggestion is not 
TABLE 2

Number of female victims in sexual assault cases, Wales, 1730-1830

\begin{tabular}{lcc}
\hline \hline Marital status or age & Rape & Attempted rape \\
\hline Married & 8 & 29 \\
Widow & 2 & 3 \\
Spinster & 11 & 22 \\
Teenaged & 2 & 2 \\
Child under 12 years & 12 & 14 \\
Servant & $4^{a}$ & $2^{b}$ \\
Not specified & 8 & 16 \\
Total & 47 & 88 \\
\hline \hline
\end{tabular}

${ }^{a}$ Includes a parish apprentice.

$b$ Two servants who accused the same master.

Source: National Library of Wales, Crime and Punishment database. The number of victims does not equal the number of incidents (Table 1) due to three double indictments for attempted rape, one man who attempted to rape two victims, eight cases of attempted rape involving more than one accused, and two cases of alleged gang rape.

T ABLE 3

Disposition of cases of sexual assault at the Court of Great Sessions, Wales, $1730-1830$

\begin{tabular}{lcc}
\hline \hline Result & Rape & Attempted rape \\
\hline No prosecution & 4 & $8^{a}$ \\
No true bill & 17 & 34 \\
Not guilty & 23 & 11 \\
Guilty & 0 & 15 \\
Guilty of common assault & 0 & 7 \\
Unknown & 10 & 33 \\
Paid victim & 2 & 0 \\
Convicted on another indictment & $2^{b}$ & $2^{c}$ \\
Quashed & 0 & 1 \\
Total & 58 & 111 \\
\hline \hline
\end{tabular}

a One case abandoned (1747) when male prosecutor bribed witnesses, and another settled on payment of fees to the court (1754).

${ }^{b}$ Two men who murdered their victim (1733).

$c$ A man accused of highway robbery (male victim, 1731), and another indicted for sexually assaulting two women (not tried on second indictment, 1799).

Source: National Library of Wales, Crime and Punishment database. Corrections have been made where the documents indicate an outcome different from that included in the database. 
that extortion was commonplace, but that Welsh women were determined to have justice and men feared prosecution. In 1825 the father of a Glamorgan defendant allegedly bribed a solicitor not to bring the necessary documents to court, suggesting that he feared for his son's life, reputation or both. ${ }^{38}$ Although it was customary in assault cases for the accused to plead guilty and pay a nominal fine, as this was cheaper than a trial, ${ }^{39}$ it was a crime to compound a felony and there may therefore have been an expectation that rape cases should be settled out of court or downgraded to attempted rape. This would have been a more favourable conclusion for the community, in view of the evident reluctance of jurors to convict on the capital charge both in England and, more especially, in Wales.

Second, since prosecutions for assault with attempt to rape could be tried at quarter sessions, it is likely that a proportion of the cases brought before a court went not to Great Sessions but to one of the more numerous local courts in Wales. Another case recorded by William Thomas in 1763 involved the rape of a woman travelling to Neath; tied up and left naked on the road until freed by passers-by, she lost no time in obtaining a warrant against her assailant. When the local magistrate cleared him, she threatened to indict them both at the next quarter sessions. ${ }^{40}$ The prevalence of sexual assault prosecutions at Welsh quarter sessions cannot be ascertained from the sources on which this article is based, and must in any case have varied between counties, but English evidence suggests that if Welsh rape victims prosecuted at quarter sessions the conviction rate would have been higher than it was at Great Sessions. ${ }^{41}$

In England, a rape conviction was most likely when the victim was a child, but in Georgian Wales not even this form of the crime was enough to persuade a jury to send a man to the gallows. A defendant's chances of acquittal were noticeably worse if he was charged with attempted rape, however, as the national conviction rate was 19 per cent over the period 1730-1830. However, only 5 of those verdicts related to children, out of a total of 14 identifiable child victims and one teenage 'idiot'. Historians have noted the importance attached to the ability of a child to provide a clear description of what had happened, but if a young girl displayed knowledge of sexual matters her reputation and veracity could be called into question and the trial would collapse. ${ }^{42}$ This may well have been the case in Wales also, but it appears that the sex of the prosecutor was important too, as only one guilty verdict was obtained (in 1827) by a child prosecutor, ${ }^{43}$ the other four by their fathers; and 57 per cent of all guilty verdicts for sexual assault involved male prosecutors. Evidently, women and girls stood a better chance of convicting their attackers if husbands and fathers prosecuted for them - perhaps tacitly reminding jurors of the 
old association between rape and property theft ${ }^{44}$ - but children were nonetheless at a disadvantage.

The seven cases in which victims were raped but obtained convictions only for the attempt are most instructive, as they suggest that it was not primarily tales of pain and vulnerability that persuaded the juries, who heard the same evidence on both counts, but attitudes weighted against female complainants and in favour of male defendants. When schoolmaster John Hughes was indicted in 1777 for raping two female pupils aged about 12 years, for example, one girl testified that he "entered her by force and against her will and then put both his arms round her waist had carnal knowledge of her and moved up and down and wet her'. The other stated that he 'put his private affair into her had carnal knowledge of her against her will and hurt her much so that she could not make water for two or three days' ${ }^{45}$ Hughes was acquitted of the first charge and the other was rejected by the grand jury, but the father of the second victim had also indicted him for attempted rape; he was convicted and sentenced to six months' imprisonment and to be of good behaviour for three years. ${ }^{46}$ Although both victims recounted events clearly indicative of rape the jury would not convict, possibly because they required more evidence but more probably because the terrified girls had not reported the abuse immediately - a gendered bias inherent in rape trials.

Medical evidence was lacking in the case of Hughes, but as few depositions survive from cases before the 1790s we cannot state with certainty when medical testimony began to take a more central role in Welsh rape trials. Nor, given that many case dispositions remain unknown, can we assume that prosecutors did not use medical evidence merely to force a better settlement. However, the presence of surgeons' depositions from the late eighteenth century coincides with higher conviction rates for attempted rape, and harsher penalties: from the late 1770s small fines were replaced by a few months in gaol, and then from the 1790 s two or three years in gaol, sometimes with hard labour and after a spell in the pillory (Table 4). Only one man was whipped, in 1776, having been rash enough to confess. ${ }^{47}$

Patterns of prosecution of rape and attempted rape and conviction of rapists can be identified within circuits and between North and South Wales. Figure 1 suggests that although the greatest number of cases was heard on the Brecon circuit, it was more difficult to obtain a conviction there than it was on the North Wales circuit. Figure 2 shows that in the three counties with the most indictments (Brecon, Montgomery and Glamorgan), cases in Brecon and Montgomery occurred in small clusters, suggesting that they related to multiple attackers or that two charges had been made against the same man. Figures for Montgomery are 
T A B LE 4

Convictions and punishments handed down for sexual assault by county, Wales, 1730-1830

\begin{tabular}{lll}
\hline \hline Year & County & \\
\hline 1762 & Anglesey & Fined 5 shillings ${ }^{b}$ (two men in same case) \\
1768 & & Fined \\
1791 & Brecon & Fined (child victim) \\
1799 & & Pilloried and imprisoned three years \\
1827 & & Two years' imprisonment at hard labour (child victim) \\
1777 & Carmarthen & Fined 1 shilling and 6 pence \\
1830 & Denbigh & Two years' imprisonment at hard labour \\
1777 & Flint & Six months' imprisonment, good behaviour three years \\
& & (child victim) \\
1803 & & Pilloried twice and imprisoned three years (child victim) \\
1818 & & One month's imprisonment ${ }^{b}$ \\
1751 & Glamorgan & Fined 1 shilling and 20 shillings (paid to victim) \\
1752 & & Fined 1 shilling (and payment to victim?) \\
1777 & & Pilloried and imprisoned six months \\
1830 & & One month's imprisonment ${ }^{b}$ (child victim) \\
1776 & Merioneth & Whipped \\
1750 & Montgomery & Fined 1 shilling ${ }^{b}$ \\
1756 & & One month's imprisonment, fined \\
1764 & & Unknown \\
1793 & & Two years' imprisonment at hard labour \\
1798 & Pembroke & Unknown \\
1826 & & Gaoled \\
\hline \hline
\end{tabular}

a There were no convictions 1730-1749.

${ }^{b}$ Guilty of common assault.

Source: National Library of Wales, Crime and Punishment database.

particularly skewed by a single case of $1758,{ }^{48}$ while accusations in Glamorgan were spread more regularly over time. This is probably related to variations in the counties' populations (Figure 3) and levels of urban development. The higher population density of the South, where Glamorgan was situated, affected access to magistrates but also provided more opportunities for the sorts of casual or workplace encounters that might lead to rape as men and women flocked south to find work either in industrial enterprises or as domestic servants. Roads, canals, ports and other transport links developed more rapidly in South Wales as a consequence of industrialisation, and by 1801 seven of the nine largest Welsh towns, all small by English standards with just 2,000 to 8,000 residents, were in the south, with four in Glamorgan (Cardiff, Merthyr Tydfil, 


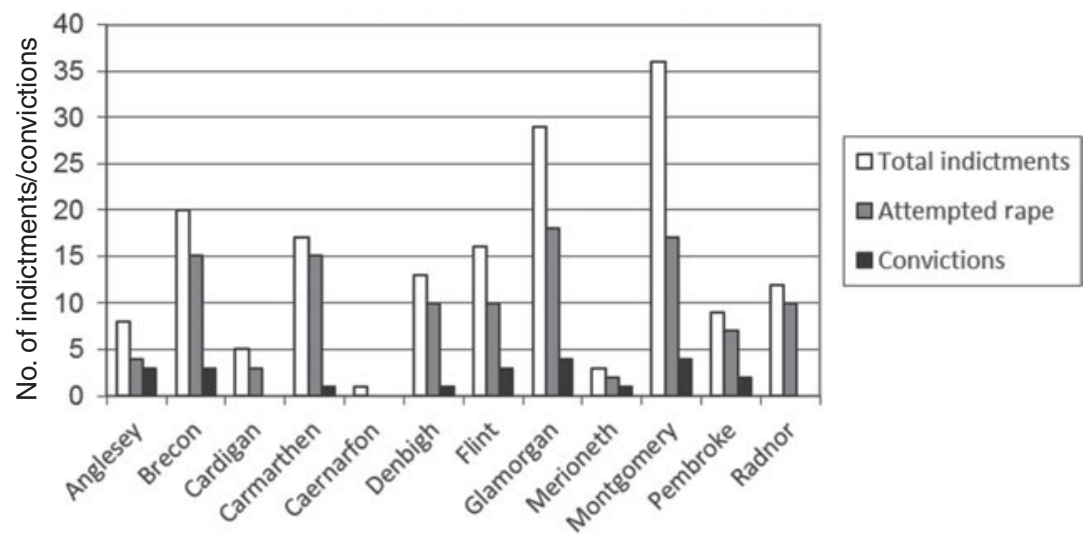

FIGURE 1. Number of indictments for rape and attempted rape, and the number of convictions for attempted rape, Wales, 1730-1830. (Source: National Library of Wales, Crime and Punishment Database.)

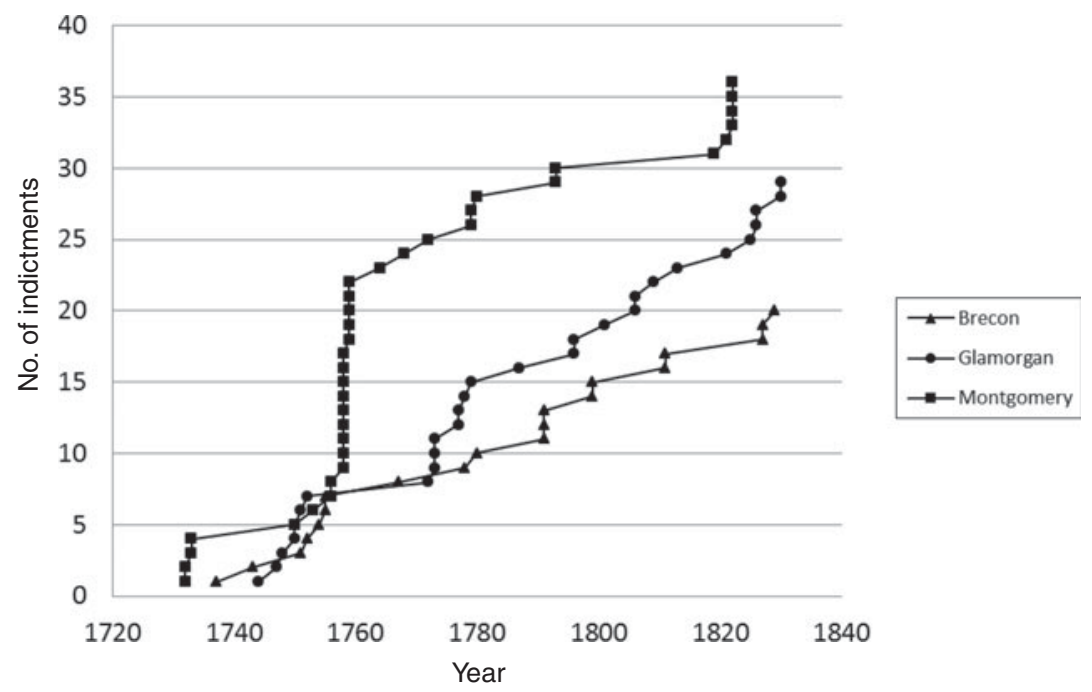

FIGURE 2. Incidence, and timing, of indictments for rape and attempted rape in selected Welsh counties, 1730-1830. Note: each symbol indicates one indictment. (Source: National Library of Wales, Crime and Punishment Database.)

Neath and Swansea). ${ }^{49}$ In the county of Surrey, in the south of England, the tendency to downgrade a rape charge to one of attempted rape was more associated with urban than rural areas, possibly because women 


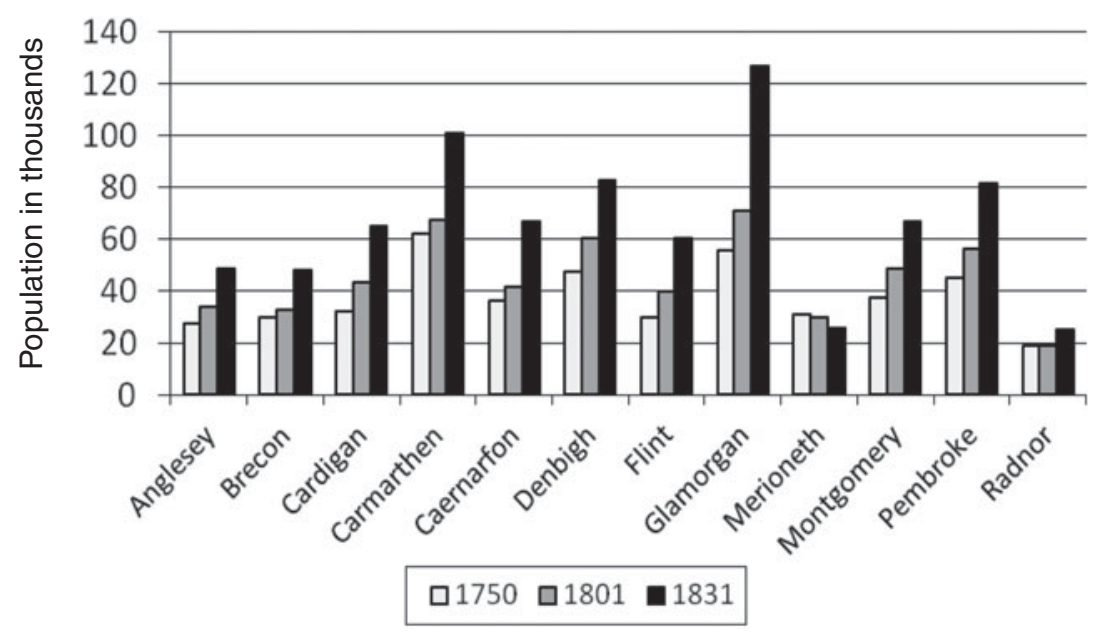

Figure 3. Population increase by county, Wales, 1750-1831. (Source: Digest of Welsh Historical Statistics 1700-1974; http://wales.gov.uk/topics/statistics/publications/dwhs17001974/?lang =en)

were more likely to be on their own, ${ }^{50}$ but in Wales prosecution for the attempt was the more common practice everywhere, including Glamorgan. Prosecutions did not become more frequent over time, indicating either that the crime was always rare in every county or that there was a lingering unwillingness to bring it into the full glare of open court. These factors offer a preliminary explanation for the higher incidence of sexual assault in the south of Wales: it was simply more common there than in the north or victims in the south were more prepared to prosecute at Great Sessions, for reasons as yet unexplained.

The persistent failure to convict men for rape is, however, the key point that this article seeks to make, as it was a peculiarity of the Principality of Wales, made all the more evident by the fact that there was no such reluctance to hang rapists in Anglicised Monmouthshire, where three men were executed for the crime during the $1820 \mathrm{~s}^{51}$ Nor did Welsh juries show any consistent willingness to punish assaults of children. Out-of-court financial settlement may have been considered a more desirable, if not the desired, outcome when Great Sessions convened, given that in Brecon, for example, 35 per cent of the indictments for sexual assault were thrown out of court whereas only 17 per cent of indictments for all crimes were rejected by the grand jury. ${ }^{52}$ It would appear, however, that social mores in Wales were beginning to change during the late eighteenth century, as convictions for attempted rape became more frequent and Welsh judges 
began to impose penalties more akin to those typical in England. ${ }^{53}$ Nevertheless, a sexual double standard remained in evidence throughout the nineteenth century: numerous cases were dismissed by magistrates, grand juries and judges, and the acquittal rate at Welsh rape trials stayed higher than in England. ${ }^{54}$

\section{HOMICIDE: INFANTICIDE, MURDER AND MANSLAUGHTER}

A substantial literature on the history of homicide in England has shown that the vast majority of accusations of murder or manslaughter were made against men. This ratio was reversed in one notable circumstance: most accusations of infanticide were brought against women. The importance of this observation is two-fold; the use of violence by men and women was dependent on gendered social contexts and these, in turn, served to influence the responses of the criminal justice system. This was manifested in several key ways. Homicide committed by women was rarely designated as manslaughter because they did not typically engage in the sudden violent confrontations, often in public places, that were understood to be the usual cause of unpremeditated killing by men. Killing by women, like their social sphere, was mainly restricted to the home and neighbourhood; urban settings, however, tended to increase levels of female criminality. Proportionally fewer women than men were indicted for or convicted of murder, but because deliberate killing embodied a stark violation of the acceptable boundaries of female behaviour, the women comprising this minority were more likely to be executed. Only women who killed their illegitimate infants without bloodshed could hope for reprieve, since they were not viewed as representing the same degree of social danger. This lenience signposted an unmistakable softening of attitudes over the course of the eighteenth century and, in 1803, a notorious statute dating from 1624, which presumed that an unmarried woman who concealed the birth and death of her child had murdered it, was repealed as outdated and ineffective. ${ }^{55}$

Table 1 confirms that few Welsh women were accused of homicide. ${ }^{56}$ Fewer still committed acts of interpersonal violence in a sole capacity, suggesting that violence committed by women was frequently motivated by communal aims and undertaken in partnership with other women and men. This is most evident in cases of attempted murder, most of which seem to have been incidents of 'assault and rescue' in which small groups of locals attacked constables or bailiffs to free a friend or relative from custody. Several murder cases similarly involved group violence that led to a death, although women were more commonly indicted with just one accessory, usually a relative. Of the 63 separate murder charges 
TABLE 5

Characteristics of female defendants in cases of homicide, Wales, $1730-1830$

\begin{tabular}{lcccr}
\hline \hline & \multicolumn{4}{c}{ Number of defendants and offence } \\
\cline { 2 - 5 } & Manslaughter & Murder & Infanticide & Total \\
\hline Defendant status & 3 & $26^{a}$ & 161 & 190 \\
Unmarried & 1 & 30 & 9 & 40 \\
Married & 1 & 7 & 14 & 22 \\
Widow & 0 & 1 & $1^{b}$ & 2 \\
Unknown & & & & \\
Relationship to victim & 3 & $9^{a}$ & 174 & 186 \\
Own infant & 0 & $10^{c}$ & 11 & 4 \\
Own child & 0 & 4 & 0 & 21 \\
Other infant/child & 1 & 6 & 0 & 6 \\
Husband & 0 & $31^{d}$ & 0 & 32 \\
Other family & 1 & & & 6 \\
Other adult & & & \\
Pty
\end{tabular}

a One woman indicted twice.

${ }^{b}$ The child was illegitimate.

$c$ Includes one niece.

$d$ Of which 22 were male, 9 female.

Source: National Library of Wales, Crime and Punishment database.

noted in Table 5, 30 women acted alone, 6 with another woman, 10 with a man, and 17 in a group of 3 or more individuals. This further reinforces the finding that with the exception of infanticide, women engaged in lethal assaults in the company of others at least as often as they did alone, and they were more often involved in such group assaults than men were. Women were usually accused of beating adult victims or striking them with an object. Strangling and poison were less common; guns and knives were almost never used.

Most of the Welsh women accused of homicide in their own right between 1730 and 1830 had killed their own child. The children of other people formed a smaller but significant victim group (see Table 5). In cases of infanticide, a combination of circumstance and law meant that most allegations were made against single mothers who had given birth alone and in secret, rarely involving another person. When another person was present, it was generally the mother of the accused or, less often, her father or the father of the child. Table 6 indicates that approximately 40 per cent of the women accused of homicide or attempted homicide 
TABLE 6

Disposition of cases of homicide and attempted homicide brought against female defendants at the Court of Great Sessions, Wales, 1730-1830

\begin{tabular}{lccccc}
\hline \hline Result & Infanticide & Murder & $\begin{array}{c}\text { Attempted } \\
\text { murder }\end{array}$ & Manslaughter & $\begin{array}{c}\text { Malicious } \\
\text { shooting }\end{array}$ \\
\hline No prosecution & 9 & $3^{a}$ & $2^{a}$ & $1^{b}$ & \\
No true bill & 65 & 18 & 11 & 1 & 3 \\
Not guilty & 77 & 34 & 2 & 1 & \\
Guilty & 3 & & 1 & & \\
Guilty, death & 3 & $3^{c}$ & & & \\
Guilty, death reprieved & 4 & 1 & & & \\
Guilty, imprisoned & $14^{d}$ & 2 & & 1 & \\
Guilty, fined & 8 & & 53 & 1 & \\
Unknown & & & 3 & & \\
True bill for assault & 2 & 3 & & & \\
Guilty of assault & $1^{f}$ & & & & \\
Insane & 186 & 64 & 77 & 5 & \\
Other & & & & & \\
Total & &
\end{tabular}

${ }^{a}$ Includes one woman who died before trial.

${ }^{b}$ Acquitted on a separate indictment for infanticide.

$c$ Two women (one tried, with her husband, for two separate murders).

${ }^{d}$ Guilty of concealing the birth, all after 1803 .

$e$ The victim was the accused woman's six-day-old infant.

${ }^{f}$ A woman who pleaded her belly in 1733; indicted and tried again, she was convicted but reprieved from execution.

Source: National Library of Wales, Crime and Punishment database. Corrections have been made where the documents indicate an outcome different from that included in the database.

were not prosecuted at all, or that a grand jury decided that the bill of indictment could not be sustained. Nearly all who were tried were acquitted, as few had resorted to extreme violence: almost two-thirds had used suffocation or strangulation. ${ }^{57}$ Of the small number of women who were found guilty, six were sentenced to death but only three were hanged - two in the 1730 s and one in $1805 .^{58}$ Most convictions occurred after 1803, when the lesser offence of concealment of birth, which carried a maximum penalty of two years' imprisonment, was introduced. Welsh jurors appear to have been eager to use this provision to punish women who might previously have escaped legal censure altogether because no one wanted to hang a woman, particularly one who had been seduced and abandoned. Concerns of this sort, combined with a growing use of medical testimony regarding the viability and cause of death of the victim, 


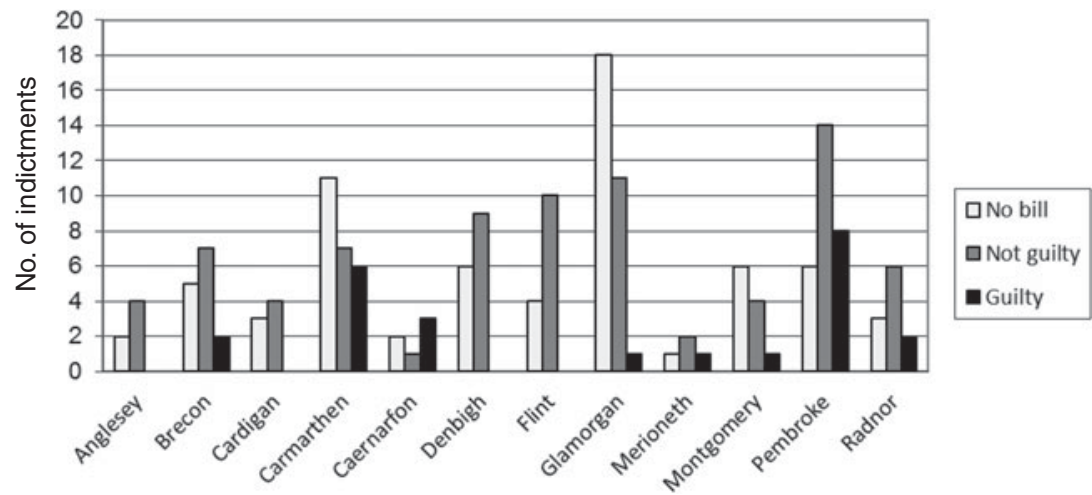

FIGURE 4. Number of indictments for infanticide by county, Wales, 1730-1830. Total indictments: Anglesey, 6; Brecon, 16; Cardigan, 10; Carmarthen, 28; Caernarfon, 7; Denbigh, 15; Flint, 15; Glamorgan, 32; Merioneth, 6; Montgomery, 11; Pembroke, 36; Radnor, 15. Excludes other outcomes listed in Table 6. (Source: National Library of Wales, Crime and Punishment Database.)

contributed to rising acquittal rates throughout England in the eighteenth century. ${ }^{59}$ In the Northern Circuit courts in England, out of nearly 200 indictments between 1720 and 1800, just 6 women were convicted, and only 2 of the 6 were executed.$^{60}$ Fifteen per cent of women tried at the Old Bailey were convicted in a similar period. ${ }^{61}$ However, not 1 of 22 women tried at Lancaster assizes between 1730 and 1760 was ${ }^{62}$ Welsh juries do not seem to have been unduly lenient or harsh in comparison with the English, and medical evidence was regularly recorded in the depositions, according well with English trends.

Infanticide was more frequently identified in the populous southern counties of Carmarthen, Glamorgan and Pembroke than in any other part of Wales (Figure 4), with cases occurring regularly throughout the period (Figure 5). It was a comparatively rare crime in North Wales. Woodward has suggested that the north-south gap may be due to differing economic structures, courtship patterns or attitudes towards violence, noting especially a correlation with the higher levels of illegitimacy in the South. ${ }^{63}$ Although little detailed work has been done on this subject, the evidence from Great Sessions suggests that the answer lies in a combination of population density (more cases and a greater likelihood of discovery and prosecution) and attitudes to unmarried mothers. The soaring cost of poor relief during the second half of the eighteenth century led to a hardening of attitudes to the poor and indigent $;{ }^{64}$ unmarried pregnant women were seen as financially and morally dangerous. This helps to explain why 18.3 per cent of indictments for infanticide were 


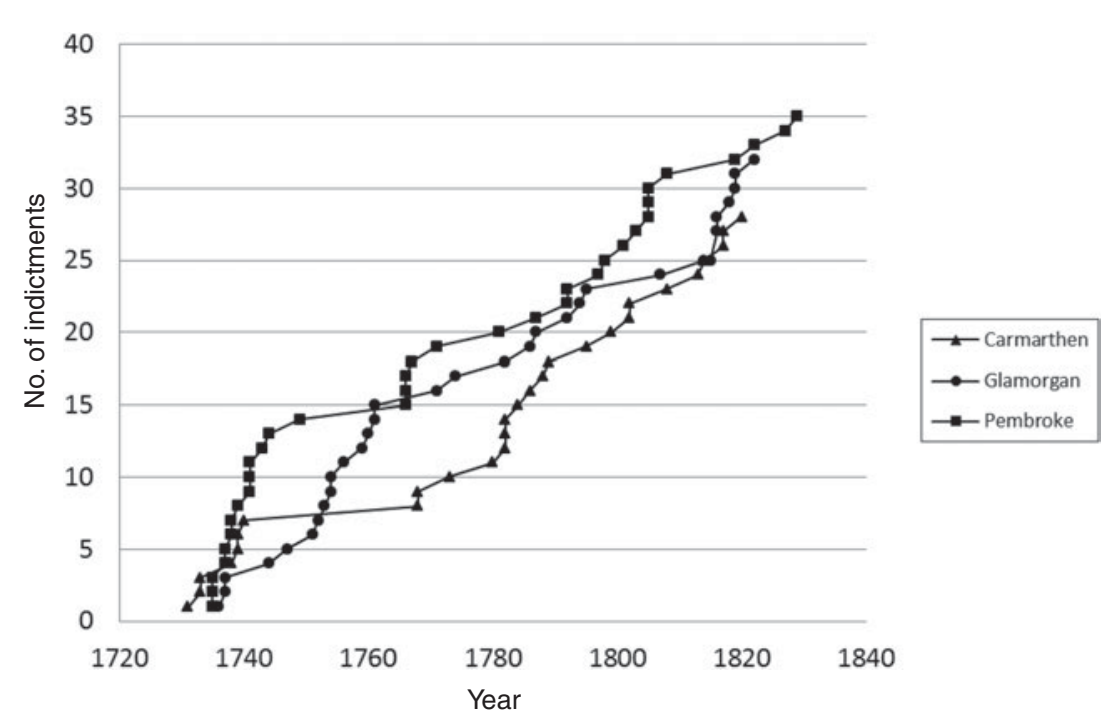

FIGURE 5. Incidence of indictments for infanticide in selected Welsh counties, 1730-1830. Note: each symbol represents one indictment. It should be noted that 92 per cent of the gaol files for Carmarthen 1741-1764 have been lost. (Source: National Library of Wales, Crime and Punishment Database.)

prosecuted by overseers, coroners or churchwardens, versus only 9 per cent of prosecutions for other forms of homicide. ${ }^{65}$ Further insight is provided by the judge who condemned Mary Morgan to death at Presteigne (Radnor) in 1805. In a letter written within days of her execution George Hardinge noted 'in our part of Wales it is thought no crime to kill a bastard-child ${ }^{,}{ }^{66}$ Also, the assertion made by Thomas Glyn Watkin that 'little stigma attached to an illegitimate child in many parts of Wales, provided the grandmother was prepared to rear the child as though it were her own' offers a clear avenue for further research, to establish the geographical boundaries of such views. ${ }^{67}$

Mary Morgan was one of a very unlucky few. The experience of most women was quite the reverse: they were rarely convicted or harshly punished for violent acts (Table 6). During the century to 1830, as Table 1 shows, 8.3 per cent of accused killers (excluding infanticide) were female, but they were not executed at a comparable rate to men. Discounting three double convictions, of 2 men and 1 woman, a total of 64 men and 3 women were sentenced to death for murder. Of these, four men and one woman were reprieved. Only two murderesses died on the gallows. In 1735, Margaret Jones and her husband confessed to the murder of two pedlars, and surviving records show that the authorities in 
Montgomeryshire, Worcestershire and Shropshire went to great lengths to establish the extent of the criminal activities of the couple and their family, which included selling goods stolen from their victims. ${ }^{68}$ Given the confessions of the two principals and their eldest son, it was inevitable that Jones should hang. Similarly, in 1801, Alice Clarke was hanged at Ruthin for the murder of her young child, despite a temporary reprieve granted when she was found to be pregnant. Other women in a similar situation were pardoned, but Clarke had confessed to a premeditated crime and was left to her fate. ${ }^{69}$ There were no legal or moral grounds on which to base a plea for mercy.

Why were other alleged murderesses more fortunate? In the absence of a confession, juries were free to acquit regardless of circumstantial evidence. In 1751, Catherine Jones was acquitted of being accessory before the fact of the murder of her lover's wife because, although she had frequently 'predicted' the woman's death, her lover, Evan Thomas, told a friend that she did not know his intentions, though he did describe her as an 'instrument of incentive', an offerin hannog in Welsh. ${ }^{70}$ In some cases the evidence of intent was simply lacking. In 1811 Sarah Davies was tried for poisoning her husband; in preparation for a guilty verdict the judge wrote out the death sentence in his notebook - but she was acquitted because there was no direct evidence she had administered the poison. ${ }^{71}$ In addition, of course, nine of the murder and manslaughter indictments related to women charged with killing their own newborn or young infant, a crime which, as we have seen, was generally viewed sympathetically by juries. How else can we explain the acquittal of Maria Williams, who in 1813 threw her infant of four months into a lead pit because the parish 'did not allow her enough towards the keep of the child', fled to Cheshire and actually admitted her deed when tracked down and arrested ? ${ }^{72}$

Acquittals of women probably relate to the same factors identified by J. M. Beattie for Surrey: most killings committed by women were not premeditated and were located within the family. However, figures for Surrey 1660-1800 suggest that 17 per cent of women tried for wilful murder were convicted, ${ }^{73}$ whereas in eighteenth-century Wales the figure was clearly much lower. Women accused of killing men were not seemingly at any greater risk of conviction, so we cannot attribute the low numbers found guilty solely to a reluctance on the part of juries to punish women who killed babies or young children. A disinclination to hold women fully accountable for their violence seems to have been a constant feature of the criminal justice system in Wales. This contrasts with other parts of Britain, where lethal violence perpetrated by women was significantly less likely to be dismissed as non-threatening or unusual. In Scotland, 60 per cent of accused murderesses were convicted; in London 
the figure was about 25 per cent. ${ }^{74}$ Historians of Welsh criminal justice have consistently identified discretion and lenience as key features of trials for property crime, as character evidence, partial verdicts and pardons mitigated the worst that the law could do ${ }^{75}$ This tolerance seems to have pertained equally strongly to violent women, and to have remained consistent over time, but partial verdicts were rare - only two murder charges led to convictions for manslaughter, in a case of assault and rescue that went badly wrong in 1816 when a bailiff was killed. ${ }^{76}$ Instead, indictments were dismissed or juries acquitted, at times despite clear evidence of guilt, influenced possibly by the low numbers of prisoners tried and personal ties between victims, defendants, witnesses and jurors. ${ }^{77}$

\section{A RELUCTANCE TO PUNISH?}

Women formed a higher proportion of the total accused of violent offences (20.8 per cent) than of all offences (15.8 per cent) at Great Sessions ${ }^{78}$ but were not punished proportionally. Rather, the Welsh defended property more intensely than people; more Welsh women were sentenced to death for capital property crimes than for homicide. Out of 798 death sentences passed down for property crimes in the period 1730-1830, 86 women were sentenced to death, including 2 women convicted and sentenced twice, although at least 59 of these women were reprieved. ${ }^{79}$ Here the Welsh reluctance to execute becomes most apparent: of 368 death sentences handed down for property offences in the period $1800-1827$, only 18 men, and no women, were hanged ${ }^{80}$ Some of those pardoned were imprisoned, others transported. Welsh women were not only hanged but also transported in small numbers. Only 283 of a total of 24,960 British women transported for all offences in the period 1787-1852 were Welsh, 21 per cent of them from Anglicised Monmouthshire and the majority after 1830 when the Welsh court system had lost its distinctiveness. ${ }^{81}$

However, there was no associated reluctance to subject Welsh women to corporal punishment. In cases where the sentence was some form of corporal punishment, women formed a sizeable minority of the convicted: of 20 people pilloried, 4 were women as were 38 per cent of those sentenced to be whipped in Wales in the period $1730-1830 .{ }^{82}$ Whipping remained a regular punishment for women convicted of larceny until 1805 when it disappears from the records. Intriguingly, for the period 1783-1802, whipping was applied to women more frequently in Wales than in England. Of whipping sentences in Wales, 28 per cent were handed down to women, whereas in Surrey they received only 15 per cent of all whipping sentences ${ }^{83}$ and in north-east England too, towards the end of 
the eighteenth century, whipping was inflicted mostly on men. ${ }^{84}$ The Welsh preference for the use of whipping as an exemplary punishment probably reflected the rural and traditional nature of society and community judgement. However, further research is needed to discover its prevalence as a punishment meted out at quarter sessions and why it was abandoned as a punishment for women at Great Sessions 15 years before statute abolished the practice. ${ }^{85}$

\section{CONCLUSION}

Nearly every woman accused of homicide in Georgian Wales walked away from court, perhaps to be met by community sanctions but safe from the ignominy of the gallows. As women were subject to corporal punishment, in the form of whipping, with apparently higher frequency than in England, the Welsh tradition of dispute resolution would seem to have tempered the application of the criminal law: the English banished or hanged offenders, but the Welsh shamed and reintegrated them by means of a public trial and possible corporal sentence. This same discretion worked against rape victims, as the Welsh reluctance to execute combined with a gendered response to sexual violence against women. Jury sympathy for the victims of serious sexual assault was exceeded by that for defendants, and the criminal justice system was less well able to counteract this than on the other side of the border with England, where 95 men were executed for rape or attempted rape in the period $1800-1827 .^{86}$

However, cases brought to court embody community judgements about violence and thus reveal something of the decision to enter a formal legal process. ${ }^{87}$ In the case of sexual assault, women were clearly determined to seek justice, but may have assumed that the best settlement was financial. It probably was: depositions tell us what they said happened, but this was rarely seen as more important than a man's life or freedom. Welsh women seem to have been consistently regarded as less significant than men, both as the victims and perpetrators of violence: the voices of rape victims were unheard and female killers were not prosecuted to the full extent of the law. The Welsh were noticeably constant in this, and markedly different from the rest of the United Kingdom, where rapists and murderesses were hanged as clear examples to others. Criminal justice in Wales reinforced gendered notions of the lesser status in society of women, but further research is needed to establish how this attitude was married to the more general Welsh distaste for capital punishment.

By establishing a more detailed appreciation of the relationship between gender and violence in pre-1830 Wales, we can begin to unpick 
national differences hidden within nineteenth-century Home Office statistics for 'England and Wales', add to our understanding of the impact of the abolition of the Welsh criminal court system, and create a more closely nuanced regional picture of legal practices. In Wales, the magistracy, for instance, played an even more central role than it did in England, because magistrates had to interpret the seriousness of offences and translate the facts into English for presentation at Great Sessions. The allegedly partial and local way in which they exercised power in Georgian Wales became a subject of debate during the Victorian era and this, combined with rapid urbanisation in South Wales, led to the appointment of the country's first stipendiary magistrate in 1843. By the early 1870 s a quarter of the 17 professional magistrates outside London were in Wales. ${ }^{88}$

As Wales was a largely rural society before 1830, evidence from the Great Sessions provides a foundation on which to compare the effects of industrialisation, which began in earnest during the 1780s and sparked mass migration into the Principality, resulting in rapid population growth. The importance of settlement patterns to the incidence of sexual assaults on servant-maids is particularly evident, isolated small farms, lonely roads and towns all having their own dangers, ${ }^{89}$ but we can also consider changes in the violence done by women, who formed a diminishing proportion of the decreasing numbers charged with murder during the nineteenth century ${ }^{90}$ Perhaps the best way to trace changing attitudes to gender and violence associated with both urbanisation and culture is through a detailed comparison of Glamorgan and Monmouthshire, the two most statistically criminal counties in Victorian Wales. Since 'the power to persuade in court - and outside it - depends on the degree to which the stories told incorporate the common-sense notions of the listeners regarding how the world works and how the people in it should behave', ${ }^{91}$ the Great Sessions material opens a window into popular and elite concepts of crime and justice. The experiences of women provide useful comparators by which historians can evaluate the socio-legal changes that occurred after 1830, when the Welsh legal system was bound more closely to England than at any previous time in history.

\section{A C K NOW LEDGEM ENTS}

I am grateful for the financial support for this research provided by the Wellcome Trust (Research Leave Award no. 082207/Z/07/Z) and Oxford Brookes University, and thank Joanne Bailey, Daniel Grey, Anne-Marie Kilday and four anonymous referees for their helpful comments on earlier drafts of this article. 


\section{ENDNOTES}

1 Bruce P. Smith, 'English criminal justice administration, 1650-1850: a historiographic essay', Law and History Review 25, 3 (2007), 593-634, here 598.

2 Greg T. Smith, 'Civilized people don't want to see that sort of thing: the decline of physical punishment in London, 1760-1840', in Carolyn Strange ed., Qualities of mercy: justice, punishment, and discretion (Vancouver, 1996), 21-51.

3 Richard McMahon ed., Crime, law and popular culture in Europe, 1500-1900 (Cullompton, 2008).

4 Shani D'Cruze and Louise A. Jackson, Women, crime and justice in England since 1660 (Basingstoke, 2009); Peter King, Crime and law in England, 1750-1840: remaking justice from the margins (Cambridge, 2006), 165-223.

5 Exceptions include Garthine Walker, Crime, gender and social order in early modern England (Cambridge, 2003); and Gregory Durston, Victims and viragos: metropolitan women, crime and the eighteenth-century justice system (Bury St Edmunds, 2007).

6 Michael Roberts and Simone Clarke eds., Women and gender in early modern Wales (Cardiff, 2000), 2.

7 Key works that investigate violence in selected English counties using quantitative methods include J. M. Beattie, Crime and the courts in England 1660-1800 (Princeton, 1986), 74-139, Walker, Crime, gender and social order, 113-58 and King, Crime and law in England; and in London, Durston, Victims and viragos.

8 A. A. Powell, 'Crime in Brecknockshire 1733-1830 as revealed by the records of the court of Great Sessions' (unpublished M.A. thesis, University of Wales, 1990), 70-5; David W. Howell, The rural poor in eighteenth-century Wales (Cardiff, 2000), 213-27; N. Woodward, 'Infanticide in Wales, 1730-1830', Welsh History Review 23, 3 (2007), 94-125; Sharon Howard, Law and disorder in early modern Wales: crime and authority in the Denbighshire courts, c.1660-1730 (Cardiff, 2008), 52-96.

9 Works on Scotland and Ireland in this period are relatively few, but include two important monograph studies: Anne-Marie Kilday, Women and violent crime in Enlightenment Scotland (Woodbridge, 2007); Neal Garnham, The courts, crime and the criminal law in Ireland 1692-1760 (Dublin, 1996).

10 Dafydd Jenkins, 'The medieval Welsh idea of law', Legal History Review 49, 3-4 (1981), 323-48; Llinos Beverley Smith, 'Disputes and settlements in medieval Wales: the role of arbitration', English Historical Review 106, 421 (1991), 835-60; Llinos Beverley Smith, 'A contribution to the history of galanas in late-medieval Wales', Studia Celtica 43, 1 (2009), 87-94.

11 John Minkes, "Wales and the "Bloody Code": the Brecon Circuit of the court of Great Sessions in the 1750s', Welsh History Review 22, 4 (2005), 673-704, here 703.

12 See Peter King, Crime, justice and discretion in England 1740-1820 (Oxford, 2000); David J. V. Jones, 'Life and death in eighteenth-century Wales: a note', Welsh History Review 10, 4 (1980-81), 536-48.

13 Strange, Qualities of mercy, 3-20; Beattie, Crime and the courts, 430-49; King, Crime, justice and discretion, 297-333.

14 Howard, Law and disorder, 96; italics added.

15 For a detailed description of the legal history of the court, see Glyn Parry, A guide to the records of Great Sessions in Wales (Aberystwyth, 1995), iv-xlix, who notes that the poor reputation of the judges was only partially deserved, and Thomas Glyn Watkin, The legal history of Wales (Cardiff, 2007), 145-67. Monmouthshire held assizes as part of the Oxford Circuit in England, and is therefore excluded from the research on which this article is based. 
16 Geraint H. Jenkins, Richard Suggett and Eryn M. White, 'The Welsh language in early modern Wales', in Geraint H. Jenkins ed., The Welsh language before the Industrial Revolution (Cardiff, 1997), 45-122, here 69.

17 In 1800 probably 70 per cent of the people spoke only Welsh: see ibid., 48, 70.

18 Garnham, Courts, crime and the criminal law in Ireland, 93-4, 112, 261.

19 Richard Suggett, 'The Welsh language and the court of Great Sessions', in Jenkins, Welsh language, 153-80, here 164; Keith Williams-Jones ed., A calendar of the Merioneth quarter sessions rolls, 1733-65 (Dolgellau, 1965), 171, 229, 245, 254; National Library of Wales, Aberystwyth (hereafter NLW), Great Sessions (GS), BC4/ 10 (1790-2), BC8/6 (1809), BC14/3 (1829) Carmarthen circuit; 4/275/2 (1774), 4/255/1 (1785), 4/259/2 (1821) North Wales circuit.

20 NLW GS, BC4/10 (1792), 4/260/3 (1824).

21 Suggett, 'The Welsh language', 164; NLW BC14/3, Mr Thomas Bishop junior and Mr George Thomas (two separate cases) - the use of ' $\mathrm{Mr}$ ' suggests educated men.

22 Suggett, 'The Welsh language', 168.

23 See, for example, Frederik Pedersen, Marriage disputes in medieval England (London, 2000), 63-4, 71-3; Ermerlinda K. M. Jarman, 'An edition of the depositions from EDC 2/6, deposition book of the consistory court of Chester, September 1558-March 1558/ 9' (unpublished MARM thesis, University of Liverpool, 2010), www.history.org.uk/ file_download.php?ts $=1310724032 \& i d=8742$ [accessed 22 August 2012]. Garnham does not reflect on this issue, but a similar process must presumably have occurred in Ireland.

24 Williams-Jones, Merioneth quarter sessions rolls, xxi-xxii, xl-xlv; Beattie, Crime and the courts, 5-6; Norma Landau, The justices of the peace 1679-1760 (Berkeley, 1984), 243-9; Geraint H. Jenkins, The foundations of modern Wales 1642-1780 (Oxford, 1987), 165-72; J. Gwynfor Jones, 'The Welsh language in local government: justices of the peace and the courts of quarter sessions c.1536-1800', in Jenkins, Welsh language, 181-206, here 200-6. Eighteenth-century Welsh quarter sessions appear to have been functionally bilingual courts, but do not constitute part of the present analysis.

25 W. M. Jacob, The clerical profession in the long eighteenth century, 1680-1840 (Oxford, 2007), 227-34; Jenkins, Foundations of modern Wales, 324-5.

26 Parry, Records of Great Sessions, xxviii.

27 Ibid., xxxv-xl; Powell, 'Crime in Brecknockshire', 16-18.

28 Parry, Records of Great Sessions, 107-10, 114-17, 123-5 (Chester), 175-6, 178 (North Wales), 276-9, 284-7, 289-92 (Brecon), 376-8, 382-4, 387-9 (Carmarthen). Figures give average survival rates of gaol files (the principal records of criminal proceedings), the maximum being two per county per year. However, the large number of unknown verdicts suggests that not all relevant documents are included in these files.

29 NLW, Crime and Punishment database, http://www.llgc.org.uk/sesiwn_fawr/index_ s.htm [accessed 17 January 2012].

30 The violent offences studied in this article comprise 7.9 per cent $(1,652)$ of the total database entries $(20,979)$. Other (e.g. riot) and more minor forms of violence (e.g. assault) have been excluded.

31 Clive Emsley, Crime and society in England 1750-1900, 4th edn. (Harlow, 2010), $24,31$.

32 William Blackstone, Commentaries on the laws of England, vol. 4 (Oxford, 1769), 210-15.

33 Beattie, Crime and the courts, 124-32; Antony E. Simpson, "The "blackmail myth" and the prosecution of rape and its attempt in 18th century London: the creation of a legal 
tradition', Journal of Criminal Law and Criminology 77 (1986), 101-50; Anna Clark, Women's silence, men's violence: sexual assault in England 1770-1845 (London, 1987); Laurie Edelstein, 'An accusation easily to be made? Rape and malicious prosecution in eighteenth-century England', American Journal of Legal History 42, 4 (1998), 351-90; Garthine Walker, 'Rereading rape and sexual violence in early modern England', Gender and History 10, 1 (1998), 1-25; Martin Ingram, 'Child sexual abuse in early modern England', in Michael J. Braddick and John Walter eds., Negotiating power in early modern society: order, hierarchy and subordination in Britain and Ireland (Cambridge, 2001), 63-84, 257-62; Antony E. Simpson, 'Popular perceptions of rape as a capital crime in eighteenth-century England: the press and the trial of Francis Charteris in the Old Bailey, February 1730', Law and History Review 22, 1 (2004), 27-70; Gregory Durston, 'Rape in the eighteenth-century metropolis: part 1', British Journal for Eighteenth-Century Studies 28, 2 (2005), 167-79; Gregory Durston, 'Rape in the eighteenth-century metropolis: part 2', British Journal for Eighteenth-Century Studies 29, 1 (2006), 15-31.

34 Simpson, 'The "Blackmail myth", 109.

35 Beattie, Crime and the courts, 411.

36 Clark, Women's silence, 58; Gwenda Morgan and Peter Rushton, Rogues, thieves and the rule of law: the problem of law enforcement in north-east England, 1718-1800 (London, 1998), 56-8, 230 note 27.

37 R. T. W. Denning ed., The diary of William Thomas 1762-1795 (Cardiff, 1995), 90.

38 NLW GS 4/638/4.

39 Williams-Jones, Merioneth quarter sessions rolls, xliii.

40 Denning, Diary of William Thomas, 79.

41 Beattie, Crime and the courts, 411, gives a total conviction rate of 63.6 per cent for attempted rape cases tried at Surrey assizes and quarter sessions 1660-1800 (33 cases); Durston, 'Rape part 2', 28 cites 47 per cent at the City of London quarter sessions, and Clark, Women's silence, 47, 151 note 4, finds about 25 per cent at Middlesex quarter sessions (191 cases, 1770-1775, 1780-1785, 1790-1795). In Sussex, the conviction rate rose from 60 per cent (10 cases, 1767-1799) to 83 per cent (18 cases, 1800-1825): Sussex criminals and victims, transcribed by M. J. Burchall (Waterlooville, 2012). There were apparently no sexual assault prosecutions at Merioneth quarter sessions 1733-1765: Williams-Jones, Merioneth quarter sessions rolls.

42 Julie Gammon, "“A denial of innocence": female juvenile victims of rape and the English legal system in the eighteenth century', in Anthony Fletcher and Stephen Hussey eds., Childhood in question: children, parents and the state (Manchester, 1999), 74-95.

43 NLW GS 4/398/2.

44 Durston, Victims and viragos, 143-4.

45 NLW GS 4/1009/8.

46 Ibid.

47 NLW GS 4/302/4/17.

48 NLW GS 4/186/1, nine Welsh Gypsies of vagrant status indicted for the rape of a married woman; all were acquitted.

49 Robert Anthony, "“A very thriving place": the peopling of Swansea in the eighteenth century', Urban History 32, 1 (2005), 68-87.

50 Beattie, Crime and the courts, 130.

51 John Jenkins (1820), Daniel James (1823) and Richard Radnor (1829).

52 Powell, 'Crime in Brecknockshire', 79. 
53 Beattie, Clark, and Morgan and Rushton show that penalties for attempted rape included fines, the pillory, or imprisonment for up to one year. In Sussex, hard labour and whipping could also be imposed.

54 David J. V. Jones, Crime in nineteenth-century Wales (Cardiff, 1992), 79-80; Russell Davies, Secret sins: sex, violence and society in Carmarthenshire 1870-1920 (Cardiff, 1996), 170-1; Jill Barber, 'Stolen goods: the sexual harassment of female servants in west Wales during the nineteenth century', Rural History 4 (1993), 123-36.

55 D'Cruze and Jackson, Women, crime and justice, 16-20, 56-7, 79-80; Walker, Crime, gender and social order, 113-58; J. M. Beattie, 'The criminality of women in eighteenth-century England', Journal of Social History 8, 4 (1975), 80-116; Anne-Marie Kilday, 'Women and crime', in Hannah Barker and Elaine Chalus eds., Women's history: Britain 1700-1850: an introduction (Abingdon, 2005), 174-93.

56 Indictments for murder and manslaughter were evenly distributed across time but most common in three counties: Cardigan (10), Glamorgan (9) and Pembroke (10). Other county totals are: Anglesey (3), Brecon (7), Caernarfon (4), Carmarthen (2), Denbigh (6), Flint (7), Merioneth (1), Montgomery (6) and Radnor (4).

57 Woodward, 'Infanticide in Wales', 115-16, 121-3.

58 NLW GS 4/178/2, 4/736/5, 4/533/3.

59 David Harley, 'The scope of legal medicine in Lancashire and Cheshire, 1660-1760', in Michael Clark and Catherine Crawford eds., Legal medicine in history (Cambridge, 1994), 45-63; Mark Jackson, New-born child murder: women, illegitimacy and the courts in eighteenth-century England (Manchester, 1996), 140-5; Mary Clayton, 'Changes in Old Bailey trials for the murder of newborn babies, 1674-1803', Continuity and Change 24, 2 (2009), 337-59.

60 Jackson, New-born child murder, 3.

61 Clayton, 'Changes in Old Bailey trials', 339.

62 Harley, 'Scope of legal medicine', 53.

63 Woodward, 'Infanticide in Wales', 102-3.

64 Jenkins, Foundations of modern Wales, 338-41.

65 A total of 36 out of 197 indictments for infanticide (17 in Carmarthen, Glamorgan and Pembroke), versus 75 out of 829 for murder and manslaughter (database search for prosecutor $=$ overseer or churchwarden or coroner). These figures represent minimum values: I have been able to identify at least one example that is not noted in the database of a murderess prosecuted by churchwardens.

66 John Nichols ed., Illustrations of the literary history of the eighteenth century, vol. 3 (London, 1818), 126.

67 Watkin, Legal history of Wales, 179.

68 NLW GS 4/178/4; Bryn Ellis, 'Horrendous murders at Wtra Wen near Llanfair Caereinion', Montgomeryshire Collections 92 (2004), 69-77.

69 NLW GS 4/66/1; GS 35/22 (Denbighshire returns of prisoners 1806-30). In 1774, Margaret Williams was convicted of a similar offence, found to be pregnant and respited (Caernarfon, GS 4/275/2).

70 NLW GS 4/272/3.

71 NLW MS 204D.

72 NLW GS 4/1017/6.

73 Beattie, Crime and the courts, 83, 97; 9.4 per cent of killers (excluding infanticide) were female, 39/415 including accessories.

74 Kilday, Women and violent crime, 55; Durston, Victims and viragos, 57. 
75 Jones, 'Life and death'; Minkes, 'Wales and the "Bloody Code"', 691-3; Howard, Law and disorder, 135-5; Melvin Humphreys, The crisis of community: Montgomeryshire 1680-1815 (Cardiff, 1996), 244-6.

76 NLW GS 4/394/6.

77 Jones, 'Life and death', 538-9.

78 Percentage for violent offences calculated using figures in Table 1; that for all offences by combining the number of accused persons designated as single, widow, married or servant $(3,309)$. This provides a very good approximation but is not exact as each database entry represents one crime, not necessarily a single individual.

79 NLW Crime and Punishment database.

80 Richard Clark, '1800-1827 public executions', http://www.capitalpunishmentuk.org/ 1800.html [accessed 29 January 2012].

81 Deirdre Beddoe, Welsh convict women: a study of women transported from Wales to Australia, 1787-1852 (Barry, 1979), 13, 22, 155-63.

82 NLW Crime and Punishment database; 123 women in a total of 325.

83 Beattie, Crime and the courts, 485-7, 612 (percentage calculated using figures in Table 10.14).

84 Morgan and Rushton, Rogues, thieves, 134.

85 Smith, 'Civilized people', 37-41, notes the growing clamour against whipping in the second half of the eighteenth century. Williams-Jones, Merioneth quarter sessions rolls lists four women (no men) whipped for petty larceny (one is in the NLW Crime and Punishment database), whereas two of six people fined for assault were female.

86 Clark, ' $1800-1827$ public executions'.

87 Richard W. Ireland, "Perhaps my mother murdered me": child death and the law in Victorian Carmarthenshire', in Christopher W. Brooks and Michael Lobban eds., Communities and courts in Britain 1150-1900 (London, 1997), 229-44, here 243.

88 Jones, Crime in nineteenth-century Wales, 224-5; House of Commons Parliamentary Papers, Stipendiary magistrates (London, 1873)-at Cardiff, Merthyr Tydfil, Pontypridd and Swansea.

89 Barber, 'Stolen goods', 124-5; Jones, Crime in nineteenth-century Wales, 79.

90 Jones, Crime in nineteenth-century Wales, 72-7.

91 Tina Loo, 'Savage mercy: native culture and the modification of capital punishment in nineteenth-century British Columbia', in Strange, Qualities of mercy, 104-29, here 116.

\section{FRENCH AND GERMAN ABSTRACTS}

Les femmes, les crimes violents et la justice pénale au Pays de Galles à l'époque georgienne

Cet article examine les démêlées que des femmes ont pu avoir avec la justice pénale au Pays de Galles avant l'abolition, en 1830, de la Cour des Grandes Sessions. Etudiant les cas d'agressions sexuelles et d'homicides, l'auteur soutient que les femmes agressées qui avaient donné la mort dans ces circonstances ont rarement été condamnées ou punies sévèrement. Mais le sort des femmes victimes de viols était traité aussi avec une telle discrétion que les agresseurs n'étaient jamais condamnés non plus. En utilisant la violence comme lentille d'approche, l'article révèle un traitement typiquement gallois de la justice pénale, et propose des données 
quantitatives sur lesquelles pourraient se construire de futures études comparatives en histoire du droit et de la criminalité en Angleterre et au Pays de Galles.

Frauen, Gewaltverbrechen und Strafjustiz im georgianischen Wales

Dieser Beitrag untersucht die Begegnungen von Frauen mit dem System der Strafjustiz in Wales im letzten Jahrhundert vor der Abschaffung des Großen Strafgerichtshofes (Court of Great Sessions) im Jahre 1830. Er greift auf Fälle sexueller Gewalt und auf Tötungsdelikte zurück und vertritt die These, dass Frauen, die jemanden töteten, selten verurteilt oder hart bestraft wurden. Eine Art geschlechtsspezifischer Ermessensvorgabe wirkte sich auch gegenüber Vergewaltigungsopfern aus, deren Verfahren niemals zu einer Verurteilung führten. Durch die Verwendung der Gewalt als Brennglas erhellt der Beitrag einen spezifisch walisischen Ansatz der Strafjustiz und bietet darüber hinaus quantitative Befunde, die sich für weitere vergleichende Studien zur Geschichte des Rechts und der Kriminalität in England und Wales als instruktiv erweisen mögen. 